\title{
Cell therapies for traumatic brain injury
}

\author{
Matthew T. Harting, M.D. ${ }^{1,2}$, James E. Baumgartner, M.D. ${ }^{3}$, Laura L. Worth, M.D., Ph.D. ${ }^{4}$, \\ Linda Ewing-Cobbs, Ph.D. ${ }^{5}$, Adrian P. Gee, Ph.D. ${ }^{6}$, Mary-Clare Day, R.N., B.S.N. ${ }^{1}$, and \\ Charles S. Cox Jr., M.D. ${ }^{1,2}$ \\ ${ }^{1}$ Department of Pediatric Surgery, University of Texas Medical School at Houston \\ ${ }^{2}$ Trauma Research Center, University of Texas Medical School at Houston \\ ${ }^{3}$ Children's Memorial Hermann Hospital \\ ${ }^{4}$ University of Texas M. D. Anderson Cancer Center, Children's Cancer Hospital \\ ${ }^{5}$ Department of Pediatrics, Children's Learning Institute, University of Texas Medical School at \\ Houston \\ ${ }^{6}$ Center for Cell and Gene Therapy, Baylor College of Medicine, Houston, Texas
}

\begin{abstract}
Preliminary discoveries of the efficacy of cell therapy are currently being translated to clinical trials. Whereas a significant amount of work has been focused on cell therapy applications for a wide array of diseases, including cardiac disease, bone disease, hepatic disease, and cancer, there continues to be extraordinary anticipation that stem cells will advance the current therapeutic regimen for acute neurological disease. Traumatic brain injury is a devastating event for which current therapies are limited. In this report the authors discuss the current status of using adult stem cells to treat traumatic brain injury, including the basic cell types and potential mechanisms of action, preclinical data, and the initiation of clinical trials.
\end{abstract}

\section{Keywords}

cell therapy; clinical trial; stem cells; traumatic brain injury

Traumatic brain injury directly affects an estimated 1.5 million Americans annually, although the resultant acute and/or chronic deficits in motor, cognitive, behavioral, and/or social functioning have equally devastating effects on friends, families, and society. ${ }^{2}$ Of the TBIs suffered each year, $~ 50,000$ deaths result, and nearly 100,000 injuries lead to life-long impairment with substantial loss of function. ${ }^{2}$ Traumatic brain injury contributes to $50 \%$ of all trauma-related deaths. ${ }^{25}$ The national economic impact is difficult to quantify, due to the highly variable nature of the disease, but has been estimated in the tens of billions of dollars annually. ${ }^{44}$ Current acute treatment of TBI is limited to controlling intracranial pressure and optimizing cerebral perfusion pressure to prevent further cerebral edema, inflammation, and cell death, while chronic treatment centers on motor, cognitive, and behavioral rehabilitation. ${ }^{2}$ Advances in early recognition, acute care, the overall trauma system, and rehabilitation strategies have led to improved survival and, consequently, survivors with

\footnotetext{
Address correspondence to: Charles S. Cox Jr., M.D., Department of Pediatric Surgery, University of Texas Medical School at Houston, 6431 Fannin Street, MSB 5.254, Houston, Texas 77030. charles.s.cox@uth.tmc.edu.

Disclosure

Dr. Cox received an unrestricted educational grant from CBR, Inc.
} 
significant motor, cognitive, and social impairments. ${ }^{59}$ Although the injured brain has shown some limited capacity to recover autonomously, no current therapeutic intervention alters the underlying pathological processes via salvage, support, repair, or replacement at the tissue, cellular, or subcellular level.

\section{Background: Stem/Progenitor Cells}

Adult stem cells are derived from a niche in a developing or developed organism. ${ }^{61}$ These cells are considered multi- or pluripotent because they can differentiate into multiple adult cell types. Examples of adult stem cells (and their respective niche) that have been used to treat neural diseases include MSCs (bone marrow), NSCs (brain), and UCB/stroma (umbilical cord), a mixture of hematopoietic stem cells and MSCs. Some adult stem cells have been shown to have the ability to differentiate into cell types from multiple germ layers. Jiang and coworkers ${ }^{23}$ discovered that adult stem cells from the bone marrow, similar to MSCs, had the ability to differentiate (phenotypically) down all 3 germ cell lines (ecto-, meso-, and endoderm). These cells, termed multipotent adult progenitor cells, were differentiated to phenotypic endothelial, hepatic, and neural cells. Some bone marrowderived cells have also shown the propensity to develop phenotypic characteristics of neural cell lineage after transplantation in animal models. ${ }^{29,38,41}$ Such transdifferentiation, both in vitro and in vivo, remains highly controversial, $8,47,68,71,74$ and the general consensus is that transdifferentiation to neural lineages, even if it occurs, is not likely to play a significant role in central nervous system repair/protection. ${ }^{12}$

Mesenchymal stem cells (also termed mesenchymal stromal cells or multipotent mesenchymal stromal cells ${ }^{22}$ ) (Fig. 1) were first discovered in 1970 when Friedenstein and colleagues ${ }^{17}$ found that certain cells from the bone marrow adhered to plastic when cultured. More than 20 years later, the ability of the MSC to proliferate extensively and differentiate down multiple lineages was identified. $6,52,53$ The criteria for defining human MSCs include: 1) adherence to plastic in standard culture conditions; 2) expression of CD105, CD73, and CD90 combined with a lack of expression of CD45, CD34, CD14 or CD11b, CD79 or CD19, and HLA-DR surface molecules; and 3) differentiation to osteoblasts, adipocytes, and chondroblasts in vitro. ${ }^{11}$ Although this finding is controversial, MSCs have also been shown to develop neural phenotypes under specific conditions in vitro ${ }^{27,60,69}$ and in vivo. ${ }^{36,42}$ Their beneficial mechanism of action may not be tissue replacement, but rather microenvironment milieu alteration through growth factor production, cell-cell interaction, or inflammatory modulation. ${ }^{26}$

Neural stem cells can be isolated from many parts of the fetal or adult brain, but the most common niche is the subventricular zone of the lateral ventricle. ${ }^{55}$ Neural stem cells expand in vitro as groups of floating cells known as neurospheres (Fig. 2). The immunophenotype of NSCs is nestin positive, although it is difficult to maintain neurospheres that are purely nestin positive. ${ }^{78}$ They are multipotent, possessing the ability to differentiate into cells of neural origin including neurons, oligodendrocytes, and astroglia. ${ }^{45,46}$ Although they are more difficult to isolate and culture, these cells hold significant potential as the progenitor cells of the neural lineage.

Umbilical cord blood is known to be rich in hematopoietic stem cells and may contain MSCs. ${ }^{63}$ The umbilical cord stroma, also known as Wharton jelly, has been shown to be rich in MSCs. ${ }^{63}$ Given the fact that these tissues are a readily available source of cells, they may prove a valuable niche for cell isolation. 


\section{Cell Therapy: Possible Mechanisms of Action}

The interactions of transplanted cells and the recipient organism or specific tissue are poorly understood. Significant investigation into potential mechanisms of action that may lead to functional recovery is yielding valuable insight (Table 1). Although recent skepticism has been expressed, differentiation into local-regional cell types and supporting cell replacement remains a possible mechanism. Although the current general consensus is that it is unlikely that bone marrow-derived cells can become functional neural cells in vivo, NSCs, having progressed further down the same lineage as the cells of the brain, may certainly have the ability to replace damaged or nonfunctioning cells after transplantation, similar to the way they seem to function endogenously when they initiate neurogenesis and migrate toward sites of injury. ${ }^{10,24,48,56}$ Increasing NSC numbers at the site of injury may improve outcome.

Stem cells may also act as supportive cells, altering the fate of damaged or diseased cells. They may improve cell survival or increase cellular proliferation ${ }^{35}$ via direct contact, or they may alter the local milieu through growth factor or chemokine secretion. When cultured with TBI brain extracts, MSCs were noted to produce growth factors, ${ }^{9}$ and in a subsequent in vivo study investigators noted increases in growth factor production with MSC therapy. ${ }^{34}$ Cells may not have to be near the area of injury to initiate neuroprotection. ${ }^{5}$ They may even affect native cells via cell fusion and the transfer of cellular material. Stem cells have been shown to preferentially migrate toward sites of inflammation and they may act on the microenvironment through the reduction of inflammation, modulation of inflammatory mediators, or alteration of local edema. It has also been postulated that transplanted MSCs could enhance angiogenesis. ${ }^{7}$

\section{Applied Preclinical Studies}

\section{Bone Marrow-Derived Stem and Progenitor Cell Therapy}

A significant amount of preclinical research evaluating the therapeutic use of bone marrowderived cells to treat TBI has come from the laboratory of Chopp and colleagues (Table 2). ${ }^{42}$ They first reported the use of bone marrow-derived cells as a therapy for TBI when they transplanted whole bone marrow adjacent to the site of injury in 2001. They found that some of the cells survived 1 month, migrated toward the site of injury, developed a phenotypic expression similar to mature neurons and astrocytes, and even improved motor function. Around that same time they reported intravenous ${ }^{31,41}$ and intraarterial ${ }^{29}$ administration of MSCs in a rat model of moderate TBI. Irrespective of the route of delivery, they found that the cells survived, migrated to the area of injury, and expressed neural cell markers. Animals treated intravenously were found to have reduced motor and neurological severity score deficits. ${ }^{41}$ The administration of bone marrow-derived progenitor cells intraarterially, as opposed to intravenously, has been shown to lead to a significantly greater biodistribution in other laboratories, ${ }^{72}$ but this could also lead to the development of cell emboli, decreasing blood flow. ${ }^{16}$

After the success of the acute therapy, Chopp and coworkers subsequently reported that MSC therapy 1 week after TBI also led to long-term functional recovery (3 months after treatment) and that the cells remained in the brain at 3 months. ${ }^{38}$ They have also shown incremental functional improvement over isolated cell therapy by combining MSCs with atorvastatin ${ }^{39}$ or by using a collagen scaffold to aid in cell delivery. ${ }^{30}$

Human MSCs administered intravenously 24 hours after TBI were also shown to migrate to the injured brain, express neural phenotypes, and improve functional outcome. ${ }^{36}$ These human MSCs were subsequently found to remain in the traumatically injured brain for 3 months, affecting long-term functional outcome. ${ }^{37}$ 


\section{Neural Stem Cell Therapy}

More than 10 years ago, Sinson and coworkers ${ }^{67}$ transplanted fetal rodent cortical tissues (200,000-300,000 cells) into the injured cortical areas of immunocompetent adult rats after creating a fluid percussion injury. Cell transplant survival was seen in $65 \%$ of animals, and neural outgrowth indicated cell interaction with the injured environment. Significant improvement in motor and cognitive function was reported. In addition, combining neural transplantation with nerve growth factor infusion also led to incremental functional improvements. Over the last decade a number of laboratories have explored the use of NSCs to treat TBI (Table $2^{3,4,28,33,40,57}$ ).

Rodent NSCs have been shown to survive for 14 months, migrate to the area of injury, and enhance motor and cognitive recovery, possibly via trophic support. ${ }^{64}$ Tate and coworkers ${ }^{70}$ reported that NSCs survived in the injured brain and migrated to the fimbria hippocampus within 3 months of implantation but that, in the presence of a fibronectin matrix, increased cell survival and migration were noted. Neural stem cells derived from embryonic or neonatal rodent brains have been conditionally immortalized ${ }^{54,66}$ or altered by retroviral vector-mediated transduction of an oncogene ${ }^{58}$ and have subsequently shown the ability to develop phenotypic characteristics of native neural cells in vivo. The degree of injury may be important in cell survival, as recent work has revealed that transplanted NSCs may survive better after mild TBI than after severe TBI. ${ }^{65}$

Adult human neurons have been shown to survive up to 4 weeks posttransplantation into traumatically injured rat cortex, but no significant improvement in behavioral function has been identified. ${ }^{49,51}$ More recently, these postmitotic human neural cells have been shown to survive for 12 weeks in immunosuppressed rats after delayed transplantation following TBI, although no improvement in behavioral function was reported..$^{79}$ Primed human NSCs transplanted into the hippocampus after fluid percussion injury in rats were found to differentiate to neurons, produce neurotropic factors, and mediate cognitive improvement. ${ }^{19}$

Human NSCs derived from embryos developed astrocytic and neural phenotypes after transplantation into rodent brains post-TBI. ${ }^{13,15,73}$ Englund et al. ${ }^{14}$ subsequently showed that the NSCs established appropriate corticothalamic and contralateral hippocampal connections, that they were able to generate action potentials, and that they received functional excitatory and inhibitory synaptic input from neighboring cells. Theirs is seminal work, as it is one of the few studies to show functional activity among the transplanted cells, as opposed to the more common (and controversial) phenotypic characteristics evaluated. Additionally, human NSCs have been shown to exert neuroprotective activity by attenuating the number of degenerating neurons in the acute and subacute period after TBI. ${ }^{21}$ Human NSCs have been shown to survive in the brain after discontinuation of immunosuppression. ${ }^{75}$ This could be particularly important, given the current controversy surrounding the immune response to these cells and whether it may be safe to administer nonautologous cells to patients. One explanation for the possible immunoprivileged nature of human NSCs is the downregulation of major histocompatibility expression. ${ }^{1}$

\section{Umbilical Cord Blood}

Chopp and colleagues have intravenously infused human UCB into rodents 24 hours after TBI and found that the cells migrated to the parenchyma of the injured brain, expressed neural and astrocytic phenotypes, and significantly reduced motor and neurological deficits. ${ }^{32}$ Although the experience using UCB cells to treat TBI is limited, other investigators have evaluated the efficacy of intravenously infused human UCB cells in nonTBI. Although the cells have been shown to migrate to the brain and improve functional recovery after ischemic ${ }^{77}$ and hemorrhagic ${ }^{50}$ brain injury, contrasting evidence has shown 
that few cells were detected in the ischemic brain and that no functional improvements resulted. ${ }^{43}$ The UCB cells may not require direct interaction with the neural tissue to initiate neuroprotection. ${ }^{5}$

\section{Keys to Evaluating Preclinical Studies}

Cell therapy is a rapidly evolving field. It is important to keep some key principles in mind when comparing cell-based therapy studies (Table 3 ). There are many details that must be clarified when determining the type of cell used. Within this review we have discussed MSCs and NSCs, but numerous other cell types, such as embryonic stem cells, exist. In addition, some NSCs have been transfected, some have been isolated from the subventricular zone, and some are derived from embryonic or fetal tissue. A detailed characterization of the cells, such as immunophenotype and passage number, enables the scientific community to reproduce and compare the work.

Many groups have evaluated the differences in biodistribution based on route of administration. Intravenous application offers easy access and the potential for a broad distribution ${ }^{41}$ but suffers from a large pulmonary first-pass effect, ${ }^{62,72}$ reducing the cells delivered to the arterial circulation significantly. Intraarterial delivery can focus the location of delivery, increasing cell number in the desired area, but may lead to unwanted emboli, restricting blood flow. Intracerebral delivery places cells at the site of the disease but is more difficult to access and may cause damage during the delivery process. Intrathecal or intraventricular delivery may also be efficacious.

The timing of cell delivery is an important variable of cell therapy. Conventional wisdom has been that earlier cell delivery, irrespective of the route or mechanism of action, would ultimately be better. This is probably because most other pharmacological interventions and interventions for TBI, or any disease in general, are more efficacious when applied earlier. Also, if the cells were to have a more difficult time traversing a closed blood-brain barrier, there would be a limited time window for administration. Additionally, the acutely produced inflammatory chemokines may act as attractants to cells, and transplanted cells may help to reduce the local inflammation. On the other hand, the acute, proinflammatory, edematous milieu after a TBI may not be an area conducive to the survival of transplanted cells. The interactions between the proinflammatory state of TBI and transplanted cells have yet to be characterized. Most groups have transplanted cells acutely ( $<24$ hours after TBI), but some investigators have shown cells in the brain and improvements in behavioral recovery after delivering cells $\geq 1$ week postinjury. ${ }^{38,64}$

Recent work has shown that transplanted cells may survive better after mild, as opposed to severe, TBI. ${ }^{65}$ This exemplifies the fact that the exact model of injury may be very important. The CCI injury model has many variables including piston speed, piston depth of penetration, and piston dwell time, which alter the severity of the injury. The other commonly used model of TBI, lateral fluid percussion, is thought to cause a slightly more diffuse injury and lead to more severe behavioral deficits. ${ }^{18}$ The species of model (and cells) used is important. Human cells are often used in animal models. ${ }^{36,37,76}$ The issue of xenotransplantation models serves to further confound the cell transplant survival/function issue. There is evidence to suggest that species-specific differences exist that may prevent engraftment. ${ }^{20}$ Additionally, there is evidence from in vitro work that some stem cells are immune privileged, but there is also evidence to the contrary. ${ }^{26}$ Some in vivo studies employ immunosuppression and some do not (Table 2). In particular, the use of calcineurin inhibitors may be a significant confounding variable.

Finally, most of the published, preclinical work applying cell therapeutics to TBI has shown that cells reach the brain, and many of these have also shown improvement in functional 
outcome. While there is no question that early results are promising, such publication bias is likely skewing the perception of the efficacy of cell therapy for TBI.

\section{Clinical Trials in Cell Therapy \\ Requirements for Cell-Based Therapy}

There are several requirements for undertaking a cellular based therapeutic intervention trial. First and foremost, there must exist a clinical infrastructure that allows access to the patients of interest (for TBI, a Level I trauma center). To undertake an advanced intervention trial, the trauma system must be well developed and highly functional prior to initiating a complex trial. In addition, a broad range of pediatric specialists, experienced and knowledgeable in the management of TBI and in cell-based therapies, is required from the following: 1) pediatric surgery, 2) pediatric neurosurgery, 3) pediatric bone marrow transplantation, 4) pediatric critical care, 5) advanced neuroimaging, and 6) pediatric neuropsychology. A Good Manufacturing Practice-certified cell therapeutics laboratory is also required for rapid cell separation and quality control. A clinical research team that has investigative experience with Food and Drug Administration/internal review board regulatory issues is invaluable.

\section{Regulations}

Currently, the Center for Biologics Evaluation and Research section of the Food and Drug Administration requires all cell-based interventions to be conducted under an investigational new drug protocol. Although there have been reports of autologous cell therapies administered outside of this regulatory oversight, this is currently unadvisable. The protocol evolution will focus on cell type, dosing considerations/toxicity monitoring, route of administration, and adverse event monitoring. As with all clinical trials, the trial must be registered with clinicaltrials.gov.

\section{Current Clinical Trials}

We began a Phase I clinical trial, evaluating the use of autologous bone marrow-derived mononuclear cells to treat children with isolated severe TBI, in which we have enrolled 7 of 10 patients and which should be complete in late 2008 or early 2009. Pediatric patients (age 5-14 years) with a postresuscitation Glasgow Coma Scale score between 5 and 8 are identified and further evaluated. Inclusion criteria also include consent within 24 hours of injury and the ability of child and caretaker to speak English (necessary for future neuropsychiatric testing). Exclusion criteria are listed in Table 4. After consent is obtained, cells are obtained via bone marrow aspiration ( $3 \mathrm{ml} / \mathrm{kg}$ body weight). The mononuclear cell fraction is isolated at the Center for Cell and Gene Therapy and 6 million cells $/ \mathrm{kg}$ are then infused intravenously (Fig. 3).

The safety of the therapy is determined by monitoring cerebral and systemic hemodynamics during harvest and infusion, neurological events (seizures, change in Glasgow Coma Scale score, cerebrovascular accident), infectious morbidity, and secondary organ injury (particularly pulmonary and hepatic). Late outcomes are determined using Glasgow Outcome Scale scores, as well as a battery of functional outcome measures. This Phase I trial will answer the question of safety with intravenous administration of autologous bone marrow cells among patients with an isolated TBI. Additionally, comparison of this small cohort with matched controls may offer limited insight into the efficacy of cell therapy for TBI and will open the door for larger clinical trials investigating optimal treatment strategy (cell number, cell type, delivery timing, and delivery route) and overall efficacy. 
Other clinical trials to evaluate cell therapy as a treatment strategy are underway or will be initiating enrollment shortly (Table 5). There are $~ 53$ clinical trials (as of late 2007) being conducted to investigate the use of cell therapy for a wide variety of diseases, the vast majority involving autologous cells isolated from the bone marrow. In addition to the TBI trial discussed above, there are several trials evaluating cell therapy for brain disease. In 2 trials researchers are evaluating autologous bone marrow, administered intraarterially, to treat patients with ischemic stroke. Another group of investigators is using autologous MSCs, administered intravenously, to treat multiple sclerosis. A third group is implanting human-derived central nervous system stem cells intracerebrally to treat patients with infantile or late-infantile neuronal ceroid lipofuscinosis (Batten disease), a disease in which a reduced amount of, or missing, palmitoyl protein thioesterase-1 enzyme or tripeptidyl peptidase- 1 enzyme leads to excessive accumulation of lipopigments in the body's tissues.

\section{Conclusions}

Significant advances in our understanding of stem cells and cell therapy have occurred over the last 2 decades. Our current ability to isolate and characterize various cell populations, combined with well-characterized animal models of TBI, should allow thorough preclinical investigation to guide future clinical trials. Cell therapy has shown promise in the management of a condition that has been resistant to previous therapeutic intervention. Steady progress in the translation of knowledge from the laboratory to the clinic will continue to build a foundation of evidence that will elucidate the role of cell therapy in the management of TBI.

\section{Acknowledgments}

Funding was received through grants nos. T32 GM008792-06 (MTH), M01 RR 02558, R21 HD042659001A1, and R01 NS04630801A1, NHLBI-Production Assistance for Cellular Therapies, Texas Higher Education Coordinating Board, Children's Memorial Hermann Hospital Foundation, and Cord Blood Registry, Inc. The clinical study referred to in this review was funded in part by Production Assistance for Cellular Therapy, a National Heart, Lung and Blood Institute federally funded contract program to support the manufacturing of therapeutic cell products

\section{References}

1. Al Nimer F, Wennersten A, Holmin S, Meijer X, Wahlberg L, Mathiesen T. MHC expression after human neural stem cell transplantation to brain contused rats. Neuroreport. 2004; 15:1871-1875. [PubMed: 15305127]

2. Anonymous: Consensus conference. Rehabilitation of persons with traumatic brain injury. NIH Consensus Development Panel on Rehabilitation of Persons With Traumatic Brain Injury. JAMA. 1999; 282:974-983. [PubMed: 10485684]

3. Bakshi A, Shimizu S, Keck CA, Cho S, LeBold DG, Morales D, et al. Neural progenitor cells engineered to secrete GDNF show enhanced survival, neuronal differentiation and improve cognitive function following traumatic brain injury. Eur J Neurosci. 2006; 23:2119-2134. [PubMed: 16630059]

4. Boockvar JA, Schouten J, Royo N, Millard M, Spangler Z, Castelbuono D, et al. Experimental traumatic brain injury modulates the survival, migration, and terminal phenotype of transplanted epidermal growth factor receptor-activated neural stem cells. Neurosurgery. 2005; 56:163-171. [PubMed: 15617599]

5. Borlongan CV, Hadman M, Sanberg CD, Sanberg PR. Central nervous system entry of peripherally injected umbilical cord blood cells is not required for neuroprotection in stroke. Stroke. 2004; 35:2385-2389. [PubMed: 15345799]

6. Caplan AI. Mesenchymal stem cells. J Orthop Res. 1991; 9:641-650. [PubMed: 1870029]

7. Caplan AI, Dennis JE. Mesenchymal stem cells as trophic mediators. J Cell Biochem. 2006; 98:1076-1084. [PubMed: 16619257] 
8. Castro RF, Jackson KA, Goodell MA, Robertson CS, Liu H, Shine HD. Failure of bone marrow cells to transdifferentiate into neural cells in vivo. Science. 2002; 297:1299. [PubMed: 12193778]

9. Chen X, Katakowski M, Li Y, Lu D, Wang L, Zhang L, et al. Human bone marrow stromal cell cultures conditioned by traumatic brain tissue extracts: growth factor production. J Neurosci Res. 2002; 69:687-691. [PubMed: 12210835]

10. Dash PK, Mach SA, Moore AN. Enhanced neurogenesis in the rodent hippocampus following traumatic brain injury. J Neurosci Res. 2001; 63:313-319. [PubMed: 11170181]

11. Dominici M, Le Blanc K, Mueller I, Slaper-Cortenbach I, Marini F, Krause D, et al. Minimal criteria for defining multipotent mesenchymal stromal cells. The International Society for Cellular Therapy position statement. Cytotherapy. 2006; 8:315-317. [PubMed: 16923606]

12. English D, Klasko SK, Sanberg PR. Elusive mechanisms of "stem cell"-mediated repair of cerebral damage. Exp Neurol. 2006; 199:10-15. [PubMed: 16730352]

13. Englund U, Björklund A, Wictorin K. Migration patterns and phenotypic differentiation of longterm expanded human neural progenitor cells after transplantation into the adult rat brain. Brain Res Dev Brain Res. 2002; 134:123-141.

14. Englund U, Björklund A, Wictorin K, Lindvall O, Kokaia M. Grafted neural stem cells develop into functional pyramidal neurons and integrate into host cortical circuitry. Proc Natl Acad Sci U S A. 2002; 99:17089-17094. [PubMed: 12471158]

15. Englund U, Fricker-Gates RA, Lundberg C, Björklund A, Wictorin K. Transplantation of human neural progenitor cells into the neonatal rat brain: extensive migration and differentiation with long-distance axonal projections. Exp Neurol. 2002; 173:1-21. [PubMed: 11771935]

16. Freyman T, Polin G, Osman H, Crary J, Lu M, Cheng L, et al. A quantitative, randomized study evaluating three methods of mesenchymal stem cell delivery following myocardial infarction. Eur Heart J. 2006; 27:1114-1122. [PubMed: 16510464]

17. Friedenstein AJ, Chailakhjan RK, Lalykina KS. The development of fibroblast colonies in monolayer cultures of guinea-pig bone marrow and spleen cells. Cell Tissue Kinet. 1970; 3:393403. [PubMed: 5523063]

18. Fujimoto ST, Longhi L, Saatman KE, Conte V, Stocchetti N, McIntosh TK. Motor and cognitive function evaluation following experimental traumatic brain injury. Neurosci Biobehav Rev. 2004; 28:365-378. [PubMed: 15341032]

19. Gao J, Prough DS, McAdoo DJ, Grady JJ, Parsley MO, Ma L, et al. Transplantation of primed human fetal neural stem cells improves cognitive function in rats after traumatic brain injury. Exp Neurol. 2006; 201:281-292. [PubMed: 16904107]

20. Grinnemo KH, Mansson A, Dellgren G, Klingberg D, Wardell E, Drvota V, et al. Xenoreactivity and engraftment of human mesenchymal stem cells transplanted into infarcted rat myocardium. J Thorac Cardiovasc Surg. 2004; 127:1293-1300. [PubMed: 15115985]

21. Hagan M, Wennersten A, Meijer X, Holmin S, Wahlberg L, Mathiesen T. Neuroprotection by human neural progenitor cells after experimental contusion in rats. Neurosci Lett. 2003; 351:149_ 152. [PubMed: 14623128]

22. Horwitz EM, Le Blanc K, Dominici M, Mueller I, Slaper-Cortenbach I, Marini FC, et al. Clarification of the nomenclature for MSC: The International Society for Cellular Therapy position statement. Cytotherapy. 2005; 7:393-395. [PubMed: 16236628]

23. Jiang Y, Jahagirdar BN, Reinhardt RL, Schwartz RE, Keene CD, Ortiz-Gonzalez XR, et al. Pluripotency of mesenchymal stem cells derived from adult marrow. Nature. 2002; 418:41-49. [PubMed: 12077603]

24. Kernie SG, Erwin TM, Parada LF. Brain remodeling due to neuronal and astrocytic proliferation after controlled cortical injury in mice. J Neurosci Res. 2001; 66:317-326. [PubMed: 11746349]

25. Kraus JF, Fife D, Conroy C. Pediatric brain injuries: the nature, clinical course, and early outcomes in a defined United States' population. Pediatrics. 1987; 79:501-507. [PubMed: 3822667]

26. Le Blanc K, Pittenger M. Mesenchymal stem cells: progress toward promise. Cytotherapy. 2005; 7:36-45. [PubMed: 16040382]

27. Long X, Olszewski M, Huang W, Kletzel M. Neural cell differentiation in vitro from adult human bone marrow mesenchymal stem cells. Stem Cells Dev. 2005; 14:65-69. [PubMed: 15725745] 
28. Lu D, Li Y, Mahmood A, Wang L, Rafiq T, Chopp M. Neural and marrow-derived stromal cell sphere transplantation in a rat model of traumatic brain injury. J Neurosurg. 2002; 97:935-940. [PubMed: 12405384]

29. Lu D, Li Y, Wang L, Chen J, Mahmood A, Chopp M. Intraarterial administration of marrow stromal cells in a rat model of traumatic brain injury. J Neurotrauma. 2001; 18:813-819. [PubMed: 11526987]

30. Lu D, Mahmood A, Qu C, Hong X, Kaplan D, Chopp M. Collagen scaffolds populated with human marrow stromal cells reduce lesion volume and improve functional outcome after traumatic brain injury. Neurosurgery. 2007; 61:596-603. [PubMed: 17881974]

31. Lu D, Mahmood A, Wang L, Li Y, Lu M, Chopp M. Adult bone marrow stromal cells administered intravenously to rats after traumatic brain injury migrate into brain and improve neurological outcome. Neuroreport. 2001; 12:559-563. [PubMed: 11234763]

32. Lu D, Sanberg PR, Mahmood A, Li Y, Wang L, Sanchez-Ramos J, et al. Intravenous administration of human umbilical cord blood reduces neurological deficit in the rat after traumatic brain injury. Cell Transplant. 2002; 11:275-281. [PubMed: 12075993]

33. Lu M, Chen J, Lu D, Yi L, Mahmood A, Chopp M. Global test statistics for treatment effect of stroke and traumatic brain injury in rats with administration of bone marrow stromal cells. J Neurosci Methods. 2003; 128:183-190. [PubMed: 12948561]

34. Mahmood A, Lu D, Chopp M. Intravenous administration of marrow stromal cells (MSCs) increases the expression of growth factors in rat brain after traumatic brain injury. J Neurotrauma. 2004; 21:33-39. [PubMed: 14987463]

35. Mahmood A, Lu D, Chopp M. Marrow stromal cell transplantation after traumatic brain injury promotes cellular proliferation within the brain. Neurosurgery. 2004; 55:1185-1193. [PubMed: 15509325]

36. Mahmood A, Lu D, Lu M, Chopp M. Treatment of traumatic brain injury in adult rats with intravenous administration of human bone marrow stromal cells. Neurosurgery. 2003; 53:697703. [PubMed: 12943585]

37. Mahmood A, Lu D, Qu C, Goussev A, Chopp M. Human marrow stromal cell treatment provides long-lasting benefit after traumatic brain injury in rats. Neurosurgery. 2005; 57:1026-1031. [PubMed: 16284572]

38. Mahmood A, Lu D, Qu C, Goussev A, Chopp M. Long-term recovery after bone marrow stromal cell treatment of traumatic brain injury in rats. J Neurosurg. 2006; 104:272-277. [PubMed: 16509501]

39. Mahmood A, Lu D, Qu C, Goussev A, Chopp M. Treatment of traumatic brain injury with a combination therapy of marrow stromal cells and atorvastatin in rats. Neurosurgery. 2007; 60:546554. [PubMed: 17327800]

40. Mahmood A, Lu D, Wang L, Chopp M. Intracerebral transplantation of marrow stromal cells cultured with neurotrophic factors promotes functional recovery in adult rats subjected to traumatic brain injury. J Neurotrauma. 2002; 19:1609-1617. [PubMed: 12542861]

41. Mahmood A, Lu D, Wang L, Li Y, Lu M, Chopp M. Treatment of traumatic brain injury in female rats with intravenous administration of bone marrow stromal cells. Neurosurgery. 2001; 49:11961204. [PubMed: 11846913]

42. Mahmood A, Lu D, Yi L, Chen JL, Chopp M. Intracranial bone marrow transplantation after traumatic brain injury improving functional outcome in adult rats. J Neurosurg. 2001; 94:589-595. [PubMed: 11302657]

43. Mäkinen S, Kekarainen T, Nystedt J, Liimatainen T, Huhtala T, Närvänen A, et al. Human umbilical cord blood cells do not improve sensorimotor or cognitive outcome following transient middle cerebral artery occlusion in rats. Brain Res. 2006; 1123:207-215. [PubMed: 17070789]

44. Max W, MacKenzie EJ, Rice DP. Head injuries: cost and consequences. J Head Trauma Rehabil. 1991; 6:76-91.

45. McKay R. Stem cells in the central nervous system. Science. 1997; 276:66-71. [PubMed: 9082987]

46. McKay R, Renfranz P, Cunningham M. Immortalized stem cells from the central nervous system. C R Acad Sci III. 1993; 316:1452-1457. [PubMed: 8087624] 
47. Mezey E, Nagy A, Szalayova I, Key S, Bratincsak A, Baffi J, et al. Comment on "Failure of bone marrow cells to transdifferentiate into neural cells in vivo". Science. 2003; 299:1184. [PubMed: 12595675]

48. Miles DK, Kernie SG. Activation of neural stem and progenitor cells after brain injury. Prog Brain Res. 2006; 157:187-197. [PubMed: 17167908]

49. Muir JK, Raghupathi R, Saatman KE, Wilson CA, Lee VM, Trojanowski JQ, et al. Terminally differentiated human neurons survive and integrate following transplantation into the traumatically injured rat brain. J Neurotrauma. 1999; 16:403-414. [PubMed: 10369560]

50. Nan Z, Grande A, Sanberg CD, Sanberg PR, Low WC. Infusion of human umbilical cord blood ameliorates neurologic deficits in rats with hemorrhagic brain injury. Ann N Y Acad Sci. 2005; 1049:84-96. [PubMed: 15965109]

51. Philips MF, Muir JK, Saatman KE, Raghupathi R, Lee VM, Trojanowski JQ, et al. Survival and integration of transplanted postmitotic human neurons following experimental brain injury in immunocompetent rats. J Neurosurg. 1999; 90:116-124. [PubMed: 10413164]

52. Pittenger MF, Mackay AM, Beck SC, Jaiswal RK, Douglas R, Mosca JD, et al. Multilineage potential of adult human mesenchymal stem cells. Science. 1999; 284:143-147. [PubMed: 10102814]

53. Prockop DJ. Marrow stromal cells as stem cells for nonhematopoietic tissues. Science. 1997; 276:71-74. [PubMed: 9082988]

54. Renfranz PJ, Cunningham MG, McKay RD. Region-specific differentiation of the hippocampal stem cell line HiB5 upon implantation into the developing mammalian brain. Cell. 1991; 66:713729. [PubMed: 1878969]

55. Reynolds BA, Weiss S. Generation of neurons and astrocytes from isolated cells of the adult mammalian central nervous system. Science. 1992; 255:1707-1710. [PubMed: 1553558]

56. Richardson RM, Sun D, Bullock MR. Neurogenesis after traumatic brain injury. Neurosurg Clin N Am. 2007; 18:169-181. [PubMed: 17244562]

57. Riess P, Zhang C, Saatman KE, Laurer HL, Longhi LG, Raghupathi R, et al. Transplanted neural stem cells survive, differentiate, and improve neurological motor function after experimental traumatic brain injury. Neurosurgery. 2002; 51:1043-1054. [PubMed: 12234415]

58. Ryder EF, Snyder EY, Cepko CL. Establishment and characterization of multipotent neural cell lines using retrovirus vector-mediated oncogene transfer. J Neurobiol. 1990; 21:356-375. [PubMed: 2307979]

59. Salmond CH, Sahakian BJ. Cognitive outcome in traumatic brain injury survivors. Curr Opin Crit Care. 2005; 11:111-116. [PubMed: 15758589]

60. Sanchez-Ramos J, Song S, Cardozo-Pelaez F, Hazzi C, Stedeford T, Willing A, et al. Adult bone marrow stromal cells differentiate into neural cells in vitro. Exp Neurol. 2000; 164:247-256. [PubMed: 10915564]

61. Scadden DT. The stem-cell niche as an entity of action. Nature. 2006; 441:1075-1079. [PubMed: 16810242]

62. Schrepfer S, Deuse T, Reichenspurner H, Fischbein MP, Robbins RC, Pelletier MP. Stem cell transplantation: the lung barrier. Transplant Proc. 2007; 39:573-576. [PubMed: 17362785]

63. Secco M, Zucconi E, Vieira NM, Fogaca LL, Cerqueira A, Carvalho MD, et al. Multipotent stem cells from umbilical cord: cord is richer than blood. Stem Cells. 2007; 26:146-150. [PubMed: 17932423]

64. Shear DA, Tate MC, Archer DR, Hoffman SW, Hulce VD, Laplaca MC, et al. Neural progenitor cell transplants promote long-term functional recovery after traumatic brain injury. Brain Res. 2004; 1026:11-22. [PubMed: 15476693]

65. Shindo T, Matsumoto Y, Wang Q, Kawai N, Tamiya T, Nagao S. Differences in the neuronal stem cells survival, neuronal differentiation and neurological improvement after transplantation of neural stem cells between mild and severe experimental traumatic brain injury. J Med Invest. 2006; 53:42-51. [PubMed: 16537995]

66. Sinden JD, Rashid-Doubell F, Kershaw TR, Nelson A, Chadwick A, Jat PS, et al. Recovery of spatial learning by grafts of a conditionally immortalized hippocampal neuroepithelial cell line into the ischaemia-lesioned hippocampus. Neuroscience. 1997; 81:599-608. [PubMed: 9316014] 
67. Sinson G, Voddi M, McIntosh TK. Combined fetal neural transplantation and nerve growth factor infusion: effects on neurological outcome following fluid-percussion brain injury in the rat. $\mathrm{J}$ Neurosurg. 1996; 84:655-662. [PubMed: 8613859]

68. Song L, Tuan RS. Transdifferentiation potential of human mesenchymal stem cells derived from bone marrow. FASEB J. 2004; 18:980-982. [PubMed: 15084518]

69. Tao H, Rao R, Ma DD. Cytokine-induced stable neuronal differentiation of human bone marrow mesenchymal stem cells in a serum/feeder cell-free condition. Dev Growth Differ. 2005; 47:423433. [PubMed: 16109040]

70. Tate MC, Shear DA, Hoffman SW, Stein DG, Archer DR, LaPlaca MC. Fibronectin promotes survival and migration of primary neural stem cells transplanted into the traumatically injured mouse brain. Cell Transplant. 2002; 11:283-295. [PubMed: 12075994]

71. Theise ND, Krause DS, Sharkis S. Comment on "Little evidence for developmental plasticity of adult hematopoietic stem cells". Science. 2003; 299:1317. [PubMed: 12610282]

72. Tolar J, O’Shaughnessy MJ, Panoskaltsis-Mortari A, McElmurry RT, Bell S, Riddle M, et al. Host factors that impact the biodistribution and persistence of multipotent adult progenitor cells. Blood. 2006; 107:4182-4188. [PubMed: 16410448]

73. Vescovi AL, Gritti A, Galli R, Parati EA. Isolation and intracerebral grafting of nontransformed multipotential embryonic human CNS stem cells. J Neurotrauma. 1999; 16:689-693. [PubMed: 10511241]

74. Wagers AJ, Sherwood RI, Christensen JL, Weissman IL. Little evidence for developmental plasticity of adult hematopoietic stem cells. Science. 2002; 297:2256-2259. [PubMed: 12215650]

75. Wennersten A, Holmin S, Al Nimer F, Meijer X, Wahlberg LU, Mathiesen T. Sustained survival of xenografted human neural stem/progenitor cells in experimental brain trauma despite discontinuation of immunosuppression. Exp Neurol. 2006; 199:339-347. [PubMed: 16490195]

76. Wennersten A, Meier X, Holmin S, Wahlberg L, Mathiesen T. Proliferation, migration, and differentiation of human neural stem/progenitor cells after transplantation into a rat model of traumatic brain injury. J Neurosurg. 2004; 100:88-96. [PubMed: 14743917]

77. Xiao J, Nan Z, Motooka Y, Low WC. Transplantation of a novel cell line population of umbilical cord blood stem cells ameliorates neurological deficits associated with ischemic brain injury. Stem Cells Dev. 2005; 14:722-733. [PubMed: 16433627]

78. Xu Y, Kimura K, Matsumoto N, Ide C. Isolation of neural stem cells from the forebrain of deceased early postnatal and adult rats with protracted post-mortem intervals. J Neurosci Res. 2003; 74:533-540. [PubMed: 14598297]

79. Zhang C, Saatman KE, Royo NC, Soltesz KM, Millard M, Schouten JW, et al. Delayed transplantation of human neurons following brain injury in rats: a long-term graft survival and behavior study. J Neurotrauma. 2005; 22:1456-1474. [PubMed: 16379583]

\section{Abbreviations used in this paper}

$\begin{array}{ll}\text { CCI } & \text { controlled cortical impact } \\ \text { MSC } & \text { mesenchymal stem cell } \\ \text { NSC } & \text { neural stem cell } \\ \text { TBI } & \text { traumatic brain injury } \\ \text { UCB } & \text { umbilical cord blood }\end{array}$




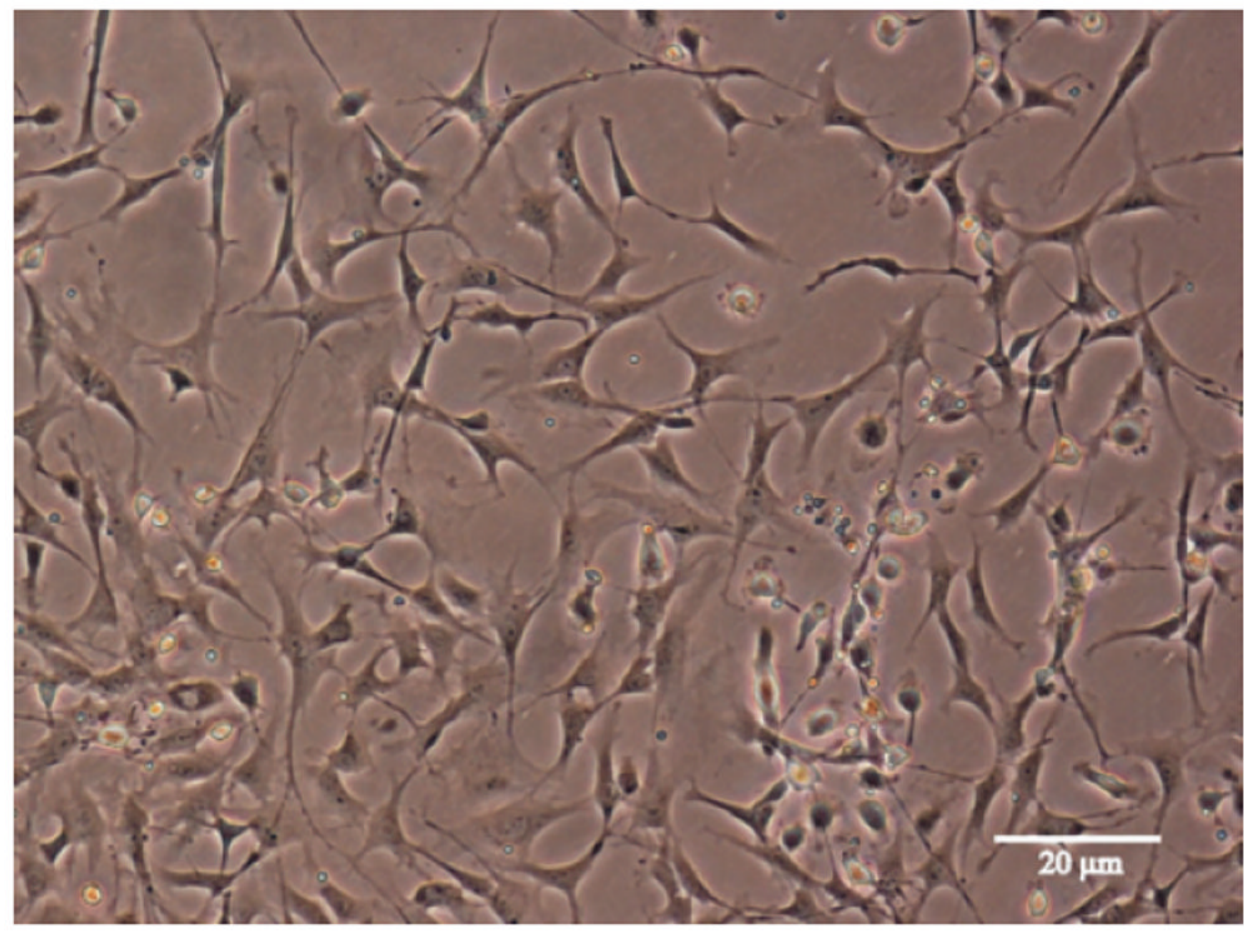

Fig. 1.

Light microscopic image showing MSCs grown in vitro after isolation from bone marrow and several passages. 

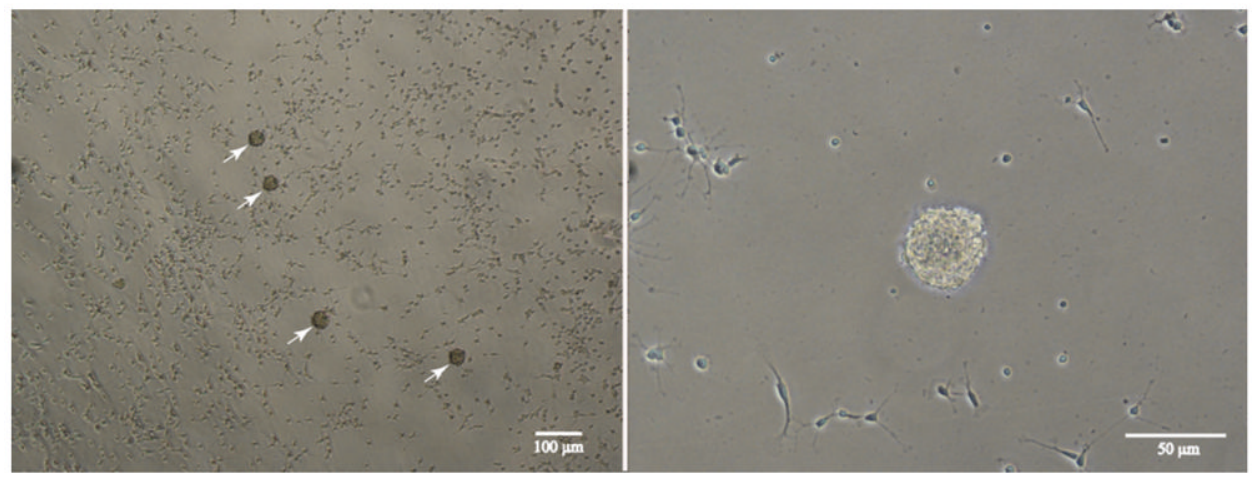

Fig. 2.

Left: Light microscopic image demonstrating NSCs (arrows) grown in vitro after isolation from the subventricular zone. Right: Light microscopic image showing a magnified view of the NSCs as groups of cells called neurospheres. 
Bone Marrow Transplantation Protocol

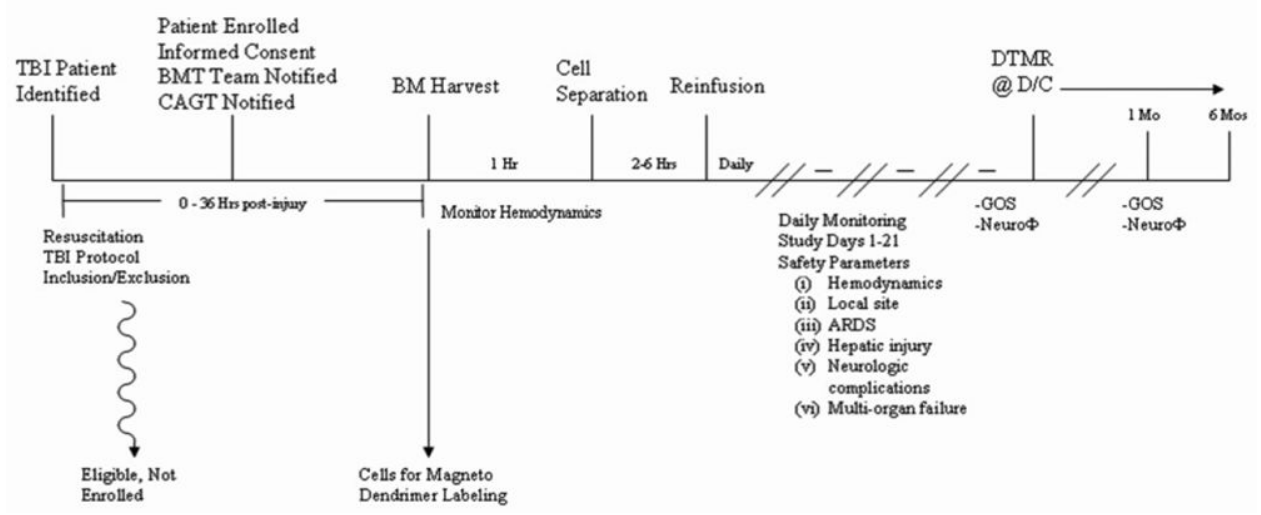

Fig. 3.

Protocol for enrollment, cell infusion, and follow-up in a Phase I clinical trial assessing the safety of autologous bone marrow cells in children after TBI. ARDS = acute respiratory distress syndrome; $\mathrm{BM}=$ bone marrow $; \mathrm{BMT}=\mathrm{BM}$ transplantation $; \mathrm{CAGT}=$ The Center for Cell and Gene Therapy; DTMR = diffusion tensor magnetic resonance (imaging); GOS $=$ Glascow Outcome Scale; Neuro = neuropsychiatric testing. 


\section{TABLE 1}

Potential mechanisms of action leading to recovery of function after adult stem cell therapy
I. cell differentiation / replacement
II. microenvironment cell support reducing cell apoptosis cell fusion
III. microenvironment alterations inflammatory modulation trophic factor production paracrine / endocrine effects
IV. angiogenesis stimulation 


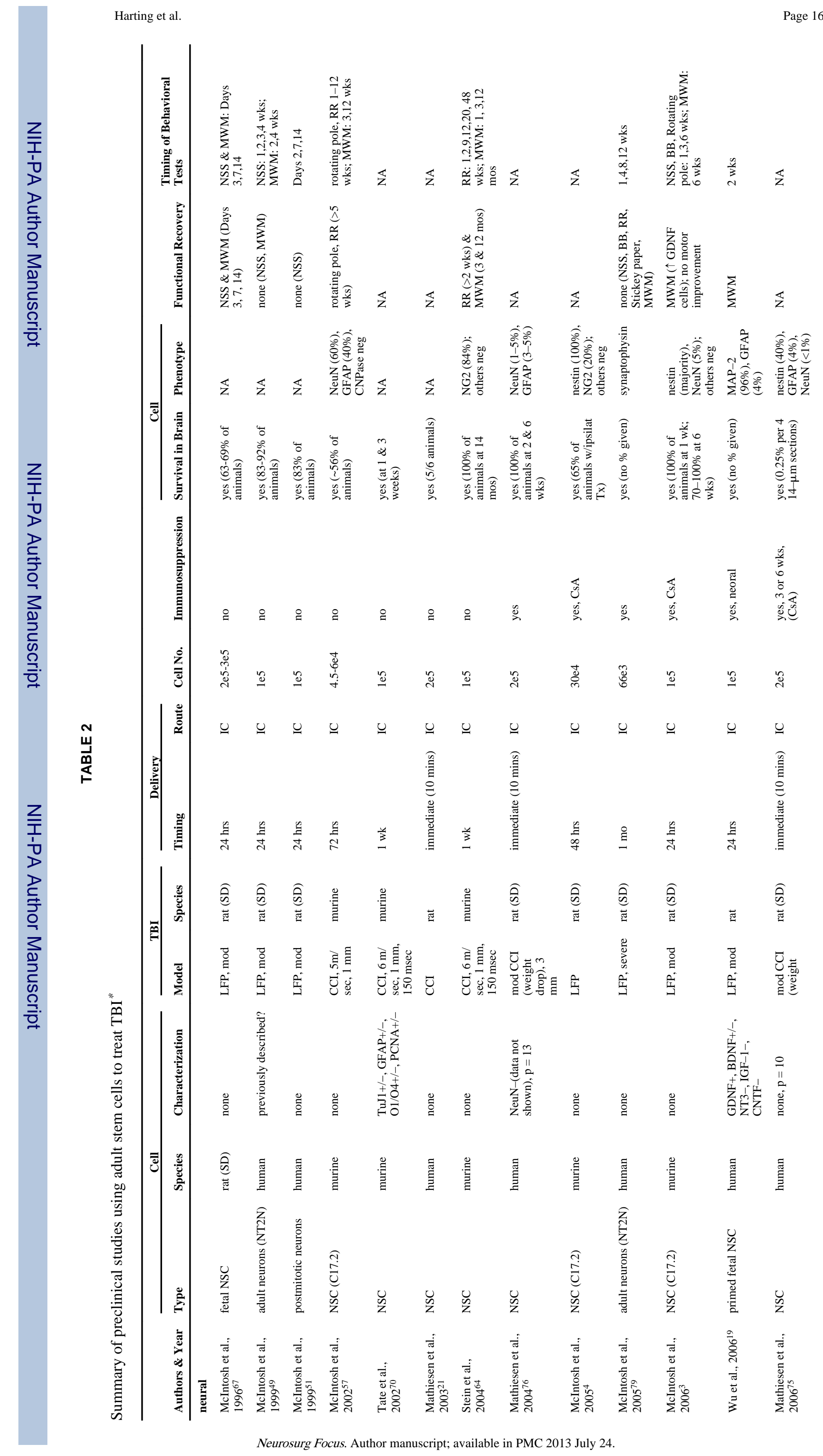




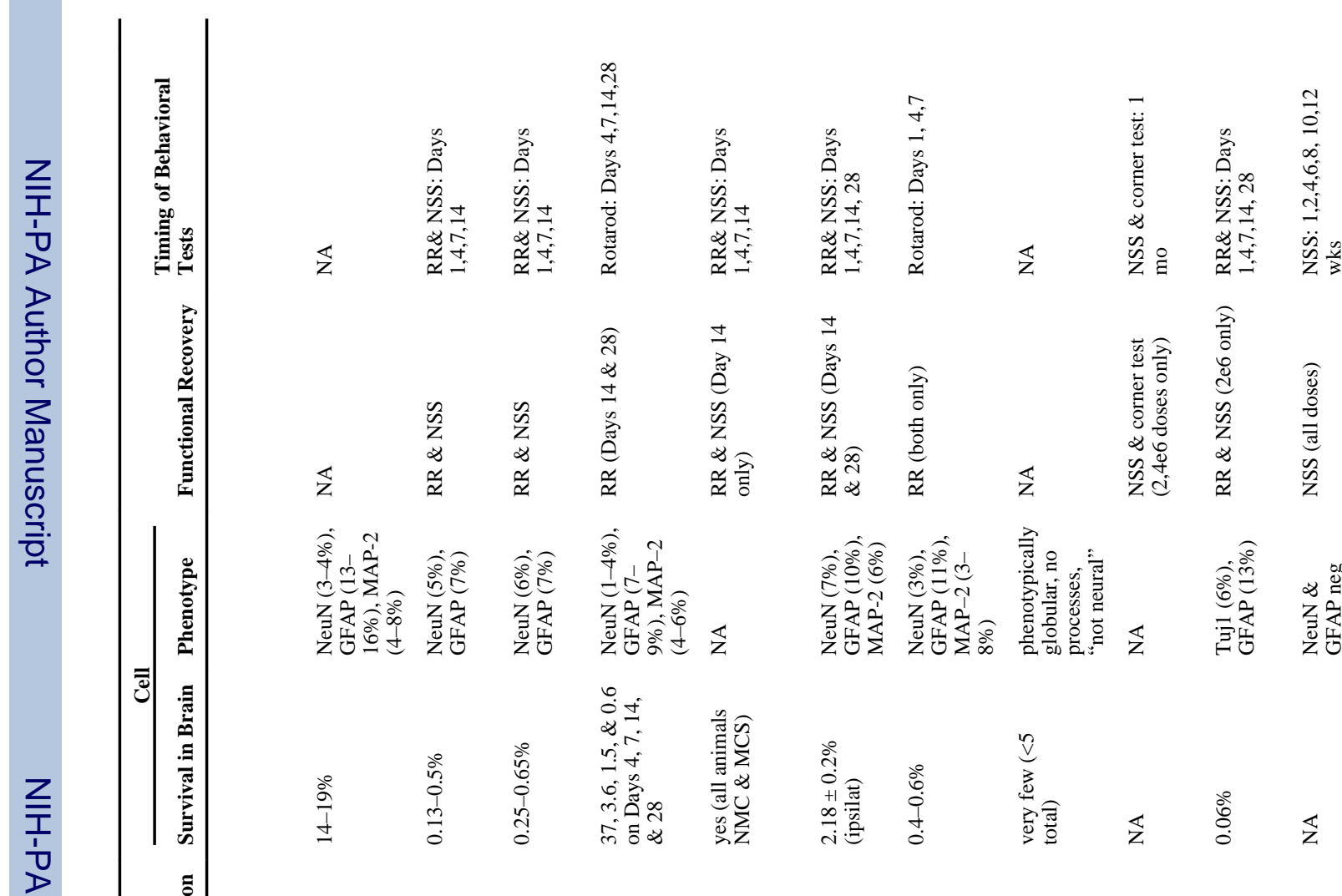


TABLE 3

Concepts critical to evaluating cell-based therapy studies

cell type
cell number
cell-labeling technique
route of administration
timing of administration
injury model
animal species
immunosuppression


TABLE 4

Exclusion criteria for the ongoing Phase I clinical trial evaluating the use of autologous bone marrow cells in children with $\mathrm{TBI}^{*}$

I. history of:

previous brain injury

developmental delay

neurological impairment/deficit

seizure disorder

recently treated infection

renal disease

hepatic disease

pulmonary disease

cancer

HIV

immunosuppression (WBC < 3e 3)

II. prolonged hypoxic ischemic insult

III. initial ICP $>40$

IV. persistent hemodynamic instability

V. uncorrected coagulopathy

VI. pelvic fracture

VII. pulmonary contusion

VIII. solid or hollow visceral injury

IX. spinal cord injury

X. persistent hypoxia

XI. positive pregnancy test

XII. participation in a concurrent intervention study

XIII. desire for organ donation

ICP = intracranial pressure; $\mathrm{WBC}=$ white blood cell. 
TABLE 5

Summary of cell therapy clinical trials currently enrolling patients or close to initiating enrollment ${ }^{*}$

\begin{tabular}{lc}
\hline Disease & No. of Clinical Trials ${ }^{\dagger}$ \\
\hline MI & 9 \\
PVD & 9 \\
CAD & 7 \\
CHF & 7 \\
cirrhosis & 3 \\
cardiomyopathy & 2 \\
diabetes & 2 \\
ischemic stroke & 2 \\
tibial fracture & 2 \\
multiple sclerosis & 2 \\
anal fistula & 1 \\
chronic wound & 1 \\
hypercholesterolemia & 1 \\
diabetic neuropathy & 1 \\
myasthenia gravis & 1 \\
osteoarthritis & 1 \\
NCL & 1 \\
TBI & 1 \\
\hline
\end{tabular}

* This search (www.clinicaltrials.gov) was performed in 2007. Search terms included "stem cell(s)" and/or "nervous system," and/or "brain"). Abbreviations: $\mathrm{MI}=$ myocardial infarction; $\mathrm{PVD}=$ peripheral vascular disease $; \mathrm{CAD}=$ coronary artery disease $\mathrm{CHF}=$ congestive heart failure; $\mathrm{NCL}=$ neuronal ceroid lipofuscinosis (Batten disease).

'This does not include cancer trials using bone marrow transplantation for recovery after chemotherapy or any trials using "stem cells" as blood/ bone marrow cell replacement. 